\title{
Całodobowy profil ciśnienia tętniczego a czynność nerek u chorych na cukrzycę typu 1
}

\author{
24-hour blood pressure monitoring and renal function in patients \\ with type 1 diabetes
}

\section{STRESZCZENIE}

Wstęp i cel. Nocny spadek ciśnienia tętniczego stwierdzany w czasie ambulatoryjnego pomiaru ciśnienia tętniczego (ABPM) uznaje się za potencjalny wskaźnik uszkodzenia narządów w cukrzycy typu 1. Celem pracy była analiza związku między profilem ciśnienia tętniczego w ABPM a innymi wskaźnikami uszkodzenia nerek u chorych na cukrzycę typu 1.

Materiał i metody. U 132 chorych na cukrzycę typu 1 z prawidłowym ciśnieniem tętniczym oraz u 22 pacjentów z rozpoznanym i leczonym nadciśnieniem tętniczym wykonano ABPM, zbadano wydalanie albumin z moczem i oszacowano wskaźnik filtracji kłębuszkowej (GFR) za pomocą cystatyny C. Poddano analizie zależności między profilem ciśnienia tętniczego w ABPM a wskaźnikami czynności nerek.

Wyniki. U normotensyjnych chorych na cukrzycę typu 1 nocny spadek ciśnienia tętniczego nie wykazywał związku z czynnością nerek. Pacjenci non-dippers cha-

Adres do korespondencji:

dr n. med. Irmina Korzeniewska-Dyl

Klinika Chorób Wewnętrznych i Nefrodiabetologii

Uniwersytetu Medycznego w Łodzi

ul. Żeromskiego 113, 90-549 Łódź

Tel. kom. +48 6024438 30; faks: +48 (42) 6393730

e-mail: irmina.korzeniewska-dyl@umed.lodz.pl

Diabetologia Kliniczna 2015, tom 4, 3, 91-97

DOI: 10.5603/DK.2015.0007

Copyright (C) 2015 Via Medica

Nadesłano: 12.04.2015

Przyjęto do druku: 03.05.2015 rakteryzowali się niższym skurczowym i rozkurczowym ciśnieniem w ciągu dnia oraz wyższym skurczowym i rozkurczowym ciśnieniem w ciągu nocy w porównaniu z pacjentami dippers. Skurczowe ciśnienie tętnicze w ciągu dnia wiązało się z niższymi wartościami GFR oszacowanymi na podstawie wartości cystatyny C. Wśród pacjentów z leczonym nadciśnieniem tętniczym w grupie non-dippers stwierdzono większe wydalanie albumin z moczem w porównaniu z chorymi z zachowanym nocnym spadkiem ciśnienia tętniczego.

Wnioski. Brak nocnego spadku ciśnienia tętniczego nie wydaje się czułym wskaźnikiem wczesnego uszkodzenia nerek u normotensyjnych chorych na cukrzycę typu 1. Jednak profil non-dippers może odzwierciedlać uszkodzenie nerek u chorych na cukrzycę typu 1 z leczonym nadciśnieniem tętniczym. Oszacowany za pomocą cystatyny $C$ GFR mógłby posłużyć za bardziej czuły niż albuminuria wskaźnik wczesnego uszkodzenia nerek w przebiegu cukrzycy typu 1. (Diabet. Klin. 2015; 4, 3: 91-97)

Słowa kluczowe: cukrzyca typu 1, monitorowanie ciśnienia tętniczego, cystatyna C, nefropatia cukrzycowa

\section{ABSTRACT}

Background and aims. Dipping profile in ambulatory blood pressure monitoring (ABPM) may be a good predictor of target organ damage in patients with type 1 diabetes. The aim of the study was to analyze the correlation 
between the blood pressure profile in ABPM and other predictors of early kidney damage in type 1 diabetes. Material and methods. We examined 132 type 1 diabetes patients with normal blood pressure and 22 type 1 diabetes patients treated with antihypertensive drugs. ABPM was performed in each patient. Urine albumin to creatinine ratio (UACR) was assessed and estimated glomerular filtration rate (eGFR) was estimated based on serum cystatin $C$ concentration. The association between blood pressure profile in ABPM and renal function was analyzed.

Results. In normotensive patients dipper status did not have any impact on renal function. Non-dippers had lower day systolic and diastolic blood pressure and higher night systolic and diastolic blood pressure than dippers. Day systolic blood pressure was negatively correlated with eGRF estimated with cystatin $C$. In hypertensive patients non-dippers had higher urine albumine to creatinine ratio than dippers.

Conclusions. In normotensive type 1 diabetic patients non-dipping status does not seem to be good predictor of early renal complications. However, in type 1 diabetics treated for hypertension, non-dipping could reflect probable kidney damage. GFR estimated with cystatin $C$ could be more sensitive than albuminuria predictor of early kidney damage in type 1 diabetes. (Diabet. Klin. 2015; 4, 3: 91-97)

Key words: type 1 diabetes, blood pressure monitoring, cystatin $\mathrm{C}$, nephropathy

\section{Wstęp}

Prawidłowe ciśnienie tętnicze u chorych na cukrzycę typu 1 wiąże się z mniejszym ryzykiem pojawienia się białkomoczu i pogorszenia funkcji nerek, a efekt ten jest niezależny od kontroli glikemii [1].

Ambulatoryjna 24-godzinna kontrola ciśnienia tętniczego (ABPM, ambulatory 24-h blood pressure monitoring) jest bardziej czuła niż kliniczny, kilkukrotny pomiar ciśnienia tętniczego we wczesnym wykrywaniu nadciśnienia tętniczego u chorych na cukrzycę typu 1 [2] . Ponadto ABPM umożliwia zaobserwowanie nieprawidłowości w dobowym rytmie ciśnienia tętniczego oraz zniesienie fizjologicznego nocnego spadku ciśnienia tętniczego (non-dipping). Postuluje się, że brak nocnego spadku ciśnienia tętniczego wiąże się z powikłaniami narządowymi w cukrzycy [3]. Wyniki ABPM wydają się odzwierciedlać ryzyko uszkodzenia nerek u chorych na cukrzycę typu 1 z prawidłowym wydalaniem albumin $z$ moczem $[4,5]$.

Pacjenci z cukrzycą typu 1, częściej niż osoby bez cukrzycy, mają status non-dippers, a brak nocnego spadku ciśnienia tętniczego może poprzedzać wystąpienie zwiększonego wydalania albumin z moczem [6-8]. Zniesienie nocnego spadku ciśnienia tętniczego może być objawem rozpoczynającej się cukrzycowej choroby nerek lub neuropatii autonomicznej $[9,10]$. Kliniczne znaczenie zjawiska nocnego spadku ciśnienia tętniczego w rozwoju powikłań nerkowych w cukrzycy nie jest jednak do końca poznane. Najczęściej obecnie używane wskaźniki uszkodzenia nerek u chorych na cukrzycę, takie jak albuminuria i szacowany wskaźnik filtracji kłębuszkowej (GFR, estimated glomerular filtration rate) na podstawie stężenia kreatyniny, mogą być niewystarczające we wczesnym etapie cukrzycowej choroby nerek.

Celem pracy była analiza zależności między wartościami ciśnienia tętniczego w ciągu całej doby oraz nocnym spadkiem ciśnienia tętniczego a wskaźnikami wczesnego uszkodzenia nerek u chorych na cukrzycę typu 1.

\section{Materiał i metody}

Badanie wykonano u pacjentów z cukrzycą typu 1 - u 132 z prawidłowym ciśnieniem tętniczym w pomiarze klinicznym oraz u 22 z rozpoznanym wcześniej i leczonym nadciśnieniem tętniczym, którzy wyrazili świadomą pisemną zgodę. Protokół badania został zatwierdzony przez Komisję Bioetyczną Uniwersytetu Medycznego w Łodzi. U każdego chorego wykonano ABPM na ręce niedominującej za pomocą tego samego przenośnego rejestratora oscylometrycznego (TrackerNIBP2 Reynolds Medical). Pacjentów pouczono, aby w czasie badania unikać nadmiernego wysiłku fizycznego, trzymać rękę rozluźnioną w czasie pomiaru oraz zanotować czas aktywności i spoczynku nocnego. Rejestrator dokonywał pomiarów co 20 minut w godzinach od 7.00 rano do 22.00 wieczorem oraz co 30 minut od godziny 22.00 wieczorem do 7.00 rano. Uzyskane w czasie rejestracji dane analizowano za pomocą programu Spacelabs Healthcare - Ambulatory Blood Pressure Monitoring for Windows Tracker 2v.O2 2.50. Wyliczono średnie wartości ciśnienia skurczowego (SBP, systolic blood pressure) i rozkurczowego (DBP, diastolic blood pressure) w ciągu 24 godzin, w ciągu aktywności dziennej oraz w czasie spoczynku nocnego. Nocny spadek SBP i DBP wyliczono na podstawie czasu snu podanego przez pacjentów. Nocny spadek SBP oraz DBP wyrażono w procentach i wyliczono ze wzoru [dzienne SBP (lub DBP) - nocne SBP (lub DBP)]/[dzienne SBP (lub DBP)] × 100\%. Pacjenci z co najmniej 10-procentowym spadkiem wartości SBP i DBP, zgodnie ze stanowiskiem European Society of Hypertension z 2013 roku, zostali zakwalifikowani jako dippers, a pozostali jako non-dippers. 
Tabela 1. Dane kliniczne i biochemiczne normotensyjnych chorych na cukrzycę typu $1(n=132)$

\begin{tabular}{lccc}
\hline Zmienna & $\begin{array}{c}\text { Dippers }(\mathbf{n}=\mathbf{7 4}) \\
\text { Mediana (min.-maks.) }\end{array}$ & $\begin{array}{c}\text { Non-dippers }(\mathbf{n}=\mathbf{5 8}) \\
\text { Mediana (min.-maks.) }\end{array}$ & $\mathbf{P}$ \\
\hline Płeć (kobiety/mężczyźni) & $40 / 34$ & $27 / 31$ & NS \\
Wiek [lata] & $26(17-54)$ & $25(20-49)$ & NS \\
Czas trwania cukrzycy [lata] & $11(2-39)$ & $10(5-34)$ & NS \\
Wskaźnik masy ciała $\left[\mathrm{kg} / \mathrm{m}^{2}\right]$ & $25,1(18,0-34,4)$ & $24,5(19,5-45,5)$ & NS \\
Cholesterol całkowity [mmol/l] & $5,20(3,12-7,12)$ & $6,62(3,18-8,04)$ & NS \\
Cholesterol frakcji LDL [mmol/l] & $2,77(1,66-5,05)$ & $2,69(1,17-5,29)$ & NS \\
Cholesterol frakcji HDL [mmol/l] & $1,58(0,83-2,51)$ & $1,47(1,01-2,31)$ & NS \\
Triglicerydy [mmol/l] & $0,98(0,45-3,04)$ & $1,04(0,52-2,84)$ & NS \\
Hemoglobina glikowana [\%] & $7,3(4,9-11,3)$ & $7,1(5,2-10,5)$ & NS \\
Białko C-reaktywne [mg/l] & $1,3(0,1-14,0)$ & $1,3(0,1-9,7)$ & NS \\
Kwas moczowy $[\mu$ mol/l] & $250(147-380)$ & $244(140-387)$ & NS \\
UACR [mg/g] & $2(0-31)$ & $3(1-114)$ & NS \\
Cystatyna C [mg/l] & $0,81(0,49-2,11)$ & $0,80(0,53-1,51)$ & NS \\
eGFR-Cys C [ml/min] & $119(24-277)$ & $122(42-243)$ & NS \\
Objawy kliniczne neuropatii & 2 & 0 & NS \\
Obecna retinopatia & 11 & 5 & NS \\
\hline
\end{tabular}

Cys C - cystatyna C; eGFR (estimated glomerular filtration rate) — szacowany wskaźnik filtracji kłębuszkowej; NS — nieistotne statystycznie; UACR (urine albumin/creatinine ratio) - stosunek albuminy do kreatyniny

U każdego pacjenta wykonano okulistyczne badanie dna oczu, zebrano wywiad dotyczący objawów neuropatii cukrzycowej, oznaczono profil lipidowy i zmierzono stężenia hemoglobiny glikowanej $\left(\mathrm{HbA}_{1 \mathrm{c}}\right)$, białka C-reaktywnego (CRP, C-reactive protein), kwasu moczowego, kreatyniny oraz cystatyny $\mathrm{C}$ w osoczu. Wydalanie albuminy z moczem wyrażono jako stosunek albuminy do kreatyniny (UACR, urine albumin/creatinine ratio), oceniony w pierwszej porannej próbce moczu. U pacjentów z UACR > 30 mg/g badanie powtórzono w ciągu kolejnych 6 miesięcy. U osób z dwoma wynikami UACR > $30 \mathrm{mg} / \mathrm{g}$ rozpoznano zwiększone wydalanie albumin z moczem.

Pomiar cystatyny C i albuminurii wykonano za pomocą metody immunoturbimetrycznej w analizatorze biochemicznym Olympus AU640. Do oznaczenia $\mathrm{HbA}_{1 c}$ użyto metody immunoinhibicji w analizatorze Olympus AU640. Oszacowano GFR na podstawie stężenia cystatyny C, używając wzoru zaproponowanego przez Grubba.

Wyniki wyrażono jako medianę i zakres, a wartość $p<0,05$ uznano za istotną statystycznie. Analizę statystyczną wykonano za pomocą oprogramowania R wersji 2.13.1 (The R Foundation for Statistical Computing). Użyto testu Shapiro-Wilka dla sprawdzenia normalności rozkładu. Dane kliniczne pacjentów dippers i non-dippers porównano za pomocą testu Manna-Whitneya dla cech mierzalnych ciągłych oraz testu $\chi^{2}$ dla zmiennych kategorycznych. Związek między wartością ciśnienia tętniczego i filtracją kłębuszkową ocenioną za pomocą analizy regresji.

\section{Wyniki}

Spośród 154 chorych na cukrzycę typu 1 u 132 stwierdzano prawidłowe ciśnienie tętnicze, a 22 przyjmowało leki hipotensyjne ( $w$ tym zawsze inhibitor konwertazy angiotesyny) z powodu rozpoznanego wcześniej nadciśnienia tętniczego. Wśród pacjentów normotensyjnych u 74 (56\%) występował nocny spadek ciśnienia tętniczego (profil dippers), a u 58 (44\%) zjawisko to było nieobecne (profil non-dippers). Spośród 22 pacjentów leczonych hipotensyjnie u 8 (36\%) stwierdzano nocny spadek ciśnienia, a u 14 (64\%) zjawisko to nie występowało.

Pacjenci normotensyjni z grupy dippers i non-dippers nie różnili się od siebie wiekiem, czasem trwania cukrzycy, wskaźnikiem masy ciała, wydalaniem albuminy z moczem (UACR), wartościami eGFR, $\mathrm{HbA}_{1 c^{\prime}}$ stężeniem cystatyny $C$, cholesterolu całkowitego, cholesterolu lipoprotein o niskiej gęstości, cholesterolu lipoprotein o wysokiej gęstości, triglicerydów, CRP oraz kwasu moczowego (tab. 1).

Porównując wartości całodobowego ciśnienia tętniczego między chorymi o profilu dippers i non-dippers, stwierdzono, że pacjenci dippers charakteryzowali się wyższymi wartościami SBP i DBP w ciągu dnia niż osoby non-dippers. Pacjenci non-dippers cechowali się wyższymi wartościami SBP i DBP w nocy niż pacjenci dippers (tab. 2). 
Tabela 2. Wartości ambulatoryjnego pomiaru ciśnienia tętniczego u normotensyjnych chorych na cukrzycę typu $1(\mathrm{n}=132)$

\begin{tabular}{lccc}
\hline Zmienna & $\begin{array}{c}\text { Dippers }(\mathbf{n}=\mathbf{7 4}) \\
\text { mediana (min.-maks.) }\end{array}$ & $\begin{array}{c}\text { Non-dippers }(\mathbf{n}=\mathbf{5 8}) \\
\text { mediana (min.-maks.) }\end{array}$ & $\mathbf{P}$ \\
\hline D_SBP & $125(101-144)$ & $119(101-166)$ & 0,0016 \\
D_DBP & $77(58-89)$ & $69(58-103)$ & $1,039 \times 10^{-5}$ \\
N_SBP & $109(88-120)$ & $111(91-151)$ & 0,0046 \\
N_DBP & $61(49-75)$ & $63(53-83)$ & 0,025 \\
D/N_sys\% & $12,3(10,1-23,2)$ & $6,7(-23,3-9,9)$ & $2,2 \times 10^{-16}$ \\
D/N_dias\% & $19,4(10,1-32,1)$ & $11,5(-41,4-19,7)$ & $3,7 \times 10^{-16}$ \\
\hline
\end{tabular}

D SBP (day systolic blood pressure) — dzienne skurczowe ciśnienie tętnicze; D DBP (day diastolic blood pressure) — dzienne rozkurczowe ciśnienie tętnicze; N_SBP (night systolic blood pressure) — nocne skurczowe ciśnienie tętnicze; N_DBP (night diastolic blood pressure) — nocne rozkurczowe ciśnienie tętnicze; D/N_sys\% — procentowy spadek skurczowego ciśnienia tętniczego w nocy; D/N_dias\% — procentowy spadek rozkurczowego ciśnienia tętniczego w nocy; NS - nieistotne statystycznie

Tabela 3. Dane kliniczne i biochemiczne normotensyjnych chorych na cukrzycę typu 1 z leczonym nadciśnieniem tętni$\operatorname{czym}(n=22)$

\begin{tabular}{|c|c|c|c|}
\hline \multirow[t]{2}{*}{ Zmienna } & \multirow{2}{*}{$\begin{array}{c}\text { Dippers }(\mathrm{n}=8) \\
\text { Mediana (min.-maks.) }\end{array}$} & \multirow{2}{*}{$\begin{array}{l}\text { Non-dippers }(\mathrm{n}=14) \\
\text { Mediana (min.-maks.) }\end{array}$} & \multirow[t]{2}{*}{$\mathbf{P}$} \\
\hline & & & \\
\hline Płeć (kobiety/mężczyźni) & $2 / 6$ & $1 / 13$ & NS \\
\hline Wiek [lata] & $25(22-32)$ & $24(19-34)$ & NS \\
\hline Czas trwania cukrzycy [lata] & $10(7-17)$ & $9(4-19)$ & NS \\
\hline Wskaźnik masy ciała $\left[\mathrm{kg} / \mathrm{m}^{2}\right]$ & $27,9(21,3-31,4)$ & $27,1(21,6-32,8)$ & NS \\
\hline Cholesterol całkowity [mmol/l] & $4,62(4,11-5,92)$ & $4,63(3,76-5,63)$ & NS \\
\hline Cholesterol frakcji LDL [mmol/l] & $2,78(1,81-3,5)$ & $2,87(1,88-3,39)$ & NS \\
\hline Cholesterol frakcji HDL [mmol/l] & $1,53(1,27-1,79)$ & $1,42(1,0-1,84)$ & NS \\
\hline Triglicerydy [mmol/l] & $1,39(0,53-2,2)$ & $1,08(0,46-1,46)$ & NS \\
\hline Hemoglobina glikowana [\%] & $7,25(6,0-8,4)$ & $6,1(5,0-8,7)$ & 0,059 \\
\hline Białko C-reaktywne [mg/l] & $1,75(0,2-8,6)$ & $1,0(0,7-5,6)$ & NS \\
\hline Kwas moczowy $[\mu \mathrm{mol} / \mathrm{l}]$ & $264(176-385)$ & $299(268-362)$ & NS \\
\hline UACR $[\mathrm{mg} / \mathrm{g}]$ & $2,5(0-26)$ & $4(1-76)$ & 0,0304 \\
\hline Cystatyna C [mg/l] & $0,85(0,66-1,01)$ & $0,83(0,73-1,41)$ & NS \\
\hline eGFR-Cys C [ml/min] & $110(83-168)$ & $115(47-142)$ & NS \\
\hline Objawy kliniczne neuropatii & 0 & 1 & NS \\
\hline Obecna retinopatia & 0 & 3 & NS \\
\hline
\end{tabular}

Cys C — cystatyna C; eGFR (estimated glomerular filtration rate) — szacowany wskaźnik filtracji kłębuszkowej; NS — nieistotne statystycznie; UACR (urine albumin/creatinine ratio) — stosunek albuminy do kreatyniny

Spośród pacjentów leczonych z powodu nadciśnienia tętniczego u osób non-dippers zanotowano istotnie wyższą wartość UACR niż u pacjentów dippers (tab. 3). Nie zaobserwowano innych różnic między pacjentami dippers i non-dippers wśród chorych leczonych hipotensyjnie (tab. 4).

U pacjentów z prawidłowymi wartościami ciśnienia tętniczego stwierdzono ujemną korelację między SBP w ciągu dnia a GFR oszacowaną przy użyciu stężenia cystatyny $\mathrm{C}$ w osoczu (ryc. 1).

\section{Dyskusja}

U osób zdrowych zarówno SBP, jak i DBP obniża się w ciągu nocy o co najmniej 10\% [11]. Zjawisko non-dipping, czyli brak nocnego spadku ciśnienia tętniczego, może wynikać z obniżonej wrażliwości baroreceptorów i być pierwszym objawem neuropatii autonomicznej [12]. Obserwowano związek braku nocnego spadku ciśnienia tętniczego ze zwiększonym wydalaniem albuminy z moczem [7, 13]. Status non-dipping jest częściej stwierdzany u pacjentów z cukrzy- 
Tabela 4. Wartości ambulatoryjnego pomiaru ciśnienia tętniczego (ABPM) u chorych na cukrzycę typu 1 z leczonym nadciśnieniem tętniczym $(\mathrm{n}=22)$

\begin{tabular}{lccc}
\hline Wartości ABPM $[\mathrm{mm} \mathrm{Hg}]$ & $\begin{array}{c}\text { Dippers }(\mathbf{n}=\mathbf{8}) \\
\text { Mediana }(\text { min.-maks. })\end{array}$ & $\begin{array}{c}\text { Non-dippers }(\mathbf{n}=14 \\
\text { Mediana (min.-maks, })\end{array}$ & P \\
\hline D_SBP & $134(122-155)$ & $128(114-150)$ & NS \\
D_DBP & $77(71-95)$ & $75(61-89)$ & NS \\
N_SBP & $115(102-135)$ & $116(104-152)$ & NS \\
N_DBP & $62(57-82)$ & $65(52-78)$ & 0,00015 \\
D/N_sys\% & $13,3(10,1-17,4)$ & $8,9(-3,4-9,9)$ & 0,0086 \\
D/N_dias\% & $19,9(13,7-22,1)$ & $14,3(3,9-21,3)$ & \\
\hline
\end{tabular}

D_SBP (day systolic blood pressure) — dzienne skurczowe ciśnienie tętnicze; D_DBP (day diastolic blood pressure) — dzienne rozkurczowe ciśnienie tętnicze; N_SBP (night systolic blood pressure) — nocne skurczowe ciśnienie tętnicze; N DBP (night diastolic blood pressure) — nocne rozkurczowe ciśnienie tętnicze; D/N_sys\% — procentowy spadek skurczowego ciśnienia tętniczego w nocy; D/N_dias\% — procentowy spadek rozkurczowego ciśnienia tętniczego w nocy; NS - nieistotne statystycznie

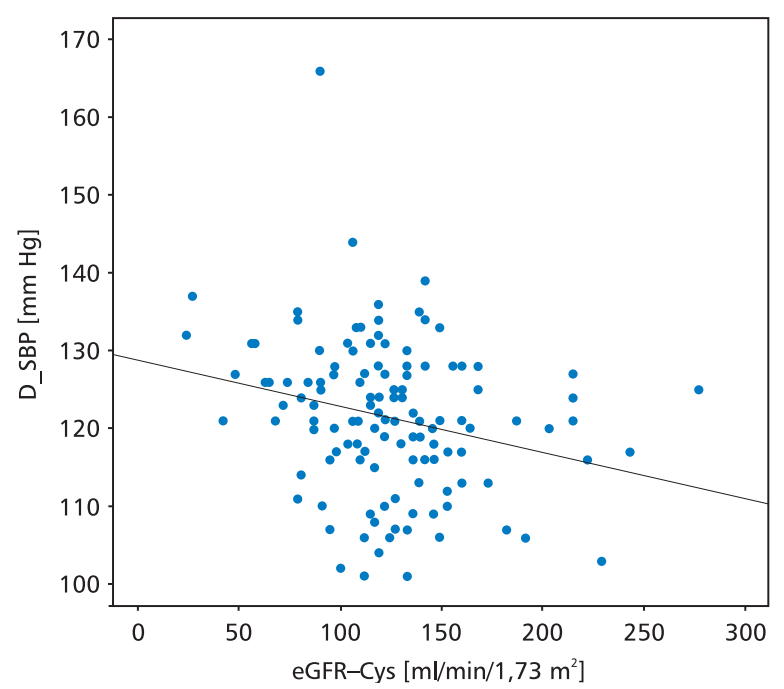

Rycina 1. Związek między ciśnieniem skurczowym w ciągu dnia (D_SBP) a szacowanym za pomocą cystatyny C wskaźnikiem filtracji kłębuszkowej (eGFR-Cys) u normotensyjnych chorych na cukrzycę typu 1 ( $n=132 ; p=0,00461)$

cą, także u tych z prawidłowym wydalaniem albumin z moczem $[6,14,15]$.

W niniejszym badaniu pacjenci normotesyjni dippers charakteryzowali się wyższymi SBP i DBP w ciągu dnia niż pacjenci non-dippers, co jest zgodne z wcześniejszymi doniesieniami [16-18]. Można to wyjaśnić zwiększonym napięciem układu współczulnego w ciągu dnia. Chorzy na cukrzycę ze zwiększonym napięciem układu współczulnego w ciągu dnia mają zachowany całodobowy profil ciśnienia tętniczego, ze spadkiem aktywności współczulnej w ciągu nocy [19, 20].

Normotesyjni pacjenci o profilu dippers charakteryzowali się istotnie niższymi wartościami SBP i DBP w ciągu nocy w porównaniu z pacjentami non- -dippers. W przypadku osób leczonych z powodu nadciśnienia nie stwierdzano takich różnic między pacjentami dippers i non-dippers. Znaczenie dziennych i nocnych wartości SBP w ABPM u chorych na cukrzycę przedstawił Torffvit [21]. W badaniu tym dzienne i nocne SBP przekraczające $140 \mathrm{~mm}$ Hg skutkowało prawie 4-krotnym wzrostem ryzyka rozwoju schyłkowej niewydolności nerek. W niniejszym badaniu wyższe SBP w ciągu dnia wiązało się z niższą filtracją kłębuszkową, co stwierdzali także inni badacze [22]. Chociaż wartości nocnego ciśnienia tętniczego nie korelowały z aktualną czynnością wydalniczą nerek badanej grupy, to uważa się, że mogą one wpływać na czynność filtracyjną nerek. Stwierdzono bowiem, że wyższe nocne SBP może być wczesnym predyktorem zmian morfologicznych w kłębuszkach nerkowych u pacjentów z cukrzycą typu 1 i prawidłowym wydalaniem albumin z moczem [23].

W grupie z prawidłowym ciśnieniem tętniczym nie zaobserwowano różnic we wskaźnikach czynności nerek. Sugeruje to, że u tych chorych dzienne wartości ciśnienia, a nie obecność nocnego spadku ciśnienia tętniczego mogą bardziej wpływać na czynność nerek.

Nie stwierdzono związku między spadkiem ciśnienia w nocy a wartością UACR, jednak w badanej populacji tylko kilku pacjentów $(n=3)$ wykazało się zwiększonym wydalaniem albumin z moczem. W niektórych badaniach profil non-dipping stanowił czynnik ryzyka zwiększonej albuminurii [24], podczas gdy w innych nie zaobserwowano związku między wydalaniem albumin i nocnym spadkiem ciśnienia tętniczego [17] bądź stwierdzano, że wartość nocnego ciśnienia skurczowego, a nie brak spadku ciśnienia w nocy sprzyja zwiększeniu albuminurii [7].

Podwyższone ciśnienie tętnicze wraz z hipertriglicerydemią są najsilniejszymi czynnikami ryzyka rozwoju i progresji zwiększonej albuminurii $[25,26]$. 
Wyniki uzyskane przez Perrin i wsp. [26] sugerują, że zwiększona albuminuria nie musi być wczesnym wskaźnikiem cukrzycowej choroby nerek, a pacjenci z prawidłową albuminurią także powinni być uważnie obserwowani pod kątem powikłań nerkowych. Wskazuje to na potrzebę zastosowania bardziej czułego i powtarzalnego wskaźnika nefropatii cukrzycowej, takiego jak cystatyna C. W badanej grupie u pacjentów z ciśnieniem tętniczym i wydalaniem albumin mieszczącym się w granicach normy zaobserwowano, że wyższe wartości SBP w ciągu dnia wiązały się z niższym GFR wyliczonym na podstawie stężenia cystatyny $C$. Cystatyna C może stanowić cenne narzędzie wczesnego wykrywania powikłań nerkowych u chorych na cukrzycę typu 1.

Zaobserwowano, że retinopatia cukrzycowa wiązała się z wyższymi wartościami dziennego i nocnego DBP [27]. W niniejszym badaniu pacjenci z retinopatią nie wykazali się większą częstością profilu non-dipping niż osoby bez retinopatii.

Sugeruje się, że profil non-dipping u chorych na cukrzycę typu 1 może być wczesnym wskaźnikiem cukrzycowej neuropatii autonomicznej [10]. Nieprawidłowe wyniki testów sercowo-naczyniowych wskazujące na neuropatię autonomiczną zaobserwowano u ponad $40 \%$ pacjentów z cukrzycą typu 1 [8]. W niniejszym badaniu testy układu autonomicznego nie były wykonywane, nie stwierdzono związku miedzy obecnością objawów klinicznych neuropatii a nocnym spadkiem ciśnienia tętniczego.

W grupie z nadciśnieniem tętniczym pacjenci non-dippers charakteryzowali się istotnie większym, chociaż nadal mieszczącym się w granicach normy, wydalaniem albumin z moczem w porównaniu z pacjentami o profilu dippers. Sugeruje to, że u osób z nadciśnieniem tętniczym brak nocnego spadku ciśnienia, mimo braku różnic w średnich wartościach ciśnienia w ciągu doby, może sprzyjać powikłaniom nerkowym, nawet w czasie leczenia działającymi nefroprotekcyjnie inhibitorami konwertazy.

\section{Wnioski}

Całodobowy pomiar ciśnienia tętniczego dostarcza istotnych informacji o zmianach wartości ciśnienia w ciągu 24 godzin. W niniejszym badaniu zaobserwowano, że brak nocnego spadku ciśnienia tętniczego jest częsty u normotensyjnych chorych na cukrzycę typu 1, ale to wartość SBP w ciągu dnia, a nie nocny spadek ciśnienia u tych chorych wiązał się z niższymi wartościami GFR. Znamiennie większa albuminuria u pacjentów non-dippers wskazuje, że brak nocnego spadku ciśnienia tętniczego wydaje się nabierać znaczenia u pacjentów z cukrzycą powikłaną nadciśnieniem tętniczym. Istotnym dla nefroprotekcji może się zatem okazać taki dobór terapii hipotensyjnej, która normalizowałaby nie tylko wartości ciśnienia tętniczego, ale też całodobowy profil ciśnienia tętniczego ze spadkiem wartości ciśnienia w ciągu nocy. Należy także rozważyć potrzebę wykorzystania innych niż albuminuria, takich jak stężenie cystatyny C, wskaźników wczesnego uszkodzenia nerek u chorych na cukrzycę typu 1.

\section{Oświadczenie o konflikcie interesów}

Autorzy nie zgłaszają konfliktu interesów.

\section{PIŚMIENNICTWO}

1. Shankar A., Klein R., Klein B., Nieto F.J., Moss SE. Relationship between low-normal blood pressure and kidney disease in type 1 diabetes. Hypertension 2007; 49: 48-54.

2. Prisant L.M., Bottini B.P., Carr A.A. Ambulatory blood pressure monitoring: methodologic issues. Am. J. Nephrol. 1996; 16: 190-201.

3. Hansen K.W., Mau P.M., Marshall S.M., Christiansen J.S., Mogensen C.E. Circadian variation of blood pressure in patient with diabetic nephropathy. Diabetologia 1992; 35: 1074-1079.

4. Mauer M., Drummond K. The early natural history of nephropathy in type 1 diabetes: II. Early renal structural changes in type 1 diabetes. Diabetes 2002; 51: 1580-1587.

5. Steinke J.M., Sinaiko A.R., Kramer M.S., Suissa S., Chavers B.M., Mauer M. The early natural history of nephropathy in type 1 diabetes: III. Predictors of 5-year urinary albumin excretion rate patterns in initially normoalbuminuric patients. Diabetes 2005; 54: 2164-2171.

6. Lurbe E., Redon J., Pascual JM., Tacons J., Alvarez V., Batlle D.C. Altered blood pressure during sleep in normotensive subjects with type I diabetes. Hypertension 1993; 21: 227-235.

7. Lurbe E., Redon J., Pascual J.M., Tacons J., Alvarez V., The spectrum of circadian blood pressure changes in type I diabetic patients. J. Hypertens. 2001; 19: 1421-428.

8. Lopes C.A.F., Lerario A.C., Mion D.Jr., Koch V., Wajchenberg B.L., Rosenbloom A.L. Ambulatory blood pressure monitoring (ABPM) in normotensive adolescents with type 1 diabetes. Pediatr. Diabetes 2002; 3: 31-36.

9. Holl R.W., Pavlovic H., Heinze E., Thon A. Circadian blood pressure during the early course of type 1 diabetes: Analysis of 1,011 blood pressure recordings in 354 adolescent and young adults. Diabetes Care 1999; 22: 1151-1157.

10. Pecis M., Azevedo M.J., Moraes R.S., Ferlin E.L., Gross J.L. Autonomic dysfunction and urinary albumin excretion rate are associated with an abnormal blood pressure pattern in normotensive normoalbuminuric type 1 diabetic patients. Diabetes Care 2000; 23: 989-993.

11. Mancia G., Parati G. Ambulatory blood pressure monitoring and organ damage. Hypertension 2000; 36: 894-900.

12. Weston P.J., Panerai R.B., McCullough A. Assessment of baroreceptor-cardiac reflex sensitivity using time domain analysis in patients with IDDM and the relation to left ventricular mass index. Diabetologia 1996; 39: 1385-1391.

13. Dost A., Klinkert C., Kapellen T., Lemmer A., Naeke A., Grabert M. Arterial hypertension determined by ambulatory blood pressure profiles: contribution to microalbuminuria risk in a multicenter investigation in 2,105 children and adolescents with type 1 diabetes. Diabetes Care 2008; 31: 720-725.

14. Van Ittersum F.J., Spek J.J., Praet I.J.A. Ambulatory blood pressures and autonomic nervous function in normoalbuminuric type I diabetic patients. Nephrol. Dial. Transplant. 1998; 13: 326-332 
15. Kempe H.P., Hasslcher C. Circadian variation of blood pressure in normo- and hypertensive diabetic patients with and without nephropathy. Z. Kardiol. 1996; 58 (supl. 3): 118-120.

16. Darcan S., Goksen D., Mir S., Serdaroglu E. i wsp. Alterations of blood pressure in type 1 diabetic children and adolescents. Pediatr. Nephrol. 2006; 21: 672-676.

17. Marcovecchio M.L., Dalton R.N., Schwarze C.P. i wsp. Ambulatory blood pressure measurements are related to albumin excretion and are predictive for risk of microalbuminuria in young people with type 1 diabetes. Diabetologia 2009; 52: 1173-1181.

18. Miller J.A., Curtis J.R., Sochett E.B. Relationship between diurnal blood pressure, renal hemodynamic function, and the renin-angiotensin system in type 1 diabetes. Diabetes 2003; 52: 1806-1811.

19. Krause M., Rudiger H., Bald M., Nake A., Paditz E. Autonomic blood pressure control in children and adolescents with type 1 diabetes mellitus. Pediatric Diabetes 2009; 10: 255-263.

20. Borel A.L., Benhamou P.Y., Baguet J.P., Debaty I. Short sleep duration is associated with a blood pressure nondipping pattern in type 1 diabetes. Diabetes Care 2009; 32: 1713-1715.

21. Torffvit $\mathrm{O}$. The effect of achieving a systolic blood pressure of $140 \mathrm{~mm} \mathrm{Hg}$. A prospective study of ambulatory measurements in type 2 diabetic patients with nephropathy. J. Diabetes. Complications 2012; 26: 540-545.

22. Mena C., Robles N.R., Martin de Prado J., Garcia Gallego F., Cidoncha A. Cystatin C and blood pressure. Results of $24 \mathrm{~h}$ ambulatory blood pressure monitoring. Eur. J. Intern. Med. 2010; 21: 185-190.

23. Perrin N.E.S.S., Torbjornsdotter T., Jaremko G.A., Berg U.B. Follow-up of kidney biopsies in normoalbuminuric patients with type 1 diabetes. Pediatr. Nephrol. 2004; 19: 1004-1013.

24. Pascual JM., Rodilla E., Gonzalez C., Pérez-Hoyos S., Redon J. Long-Term Impact of Systolic Blood Pressure and Glycemia on the Development of Microalbuminuria in Essential Hypertension. Hypertension 2005; 45: 1125-1130.

25. Evans T.C., Capell P. Diabetic nephropathy (Letter to the Editor). Clin. Diabetes 2000; 1: 7-13.

26. Perrin N.E.S.S., Torbjornsdotter T., Jaremko G.A., Berg U.B. Risk markers of future microalbuminuria and hypertension based on clinical and morphological parameters in young type 1 diabetes patients. Pediatric Diabetes 2010; 11: 305-313.

27. Kilpatrick E.S., Rigby A.S., Atkin S.L. The role of blood pressure variability in the development of nephropathy in type 1 diabetes. Diabetes Care 2010; 33: 2442-2447. 